University of Montana

ScholarWorks at University of Montana

2005

\title{
The resurrection of Erigeron parryi (Asteraceae)
}

Peter Lesica

University of Montana, Missoula

Follow this and additional works at: https://scholarworks.umt.edu/herbarium_pubs

\section{Let us know how access to this document benefits you.}

\section{Recommended Citation}

Lesica, P. 2005. The resurrection of Erigeron parryi (Asteraceae) Brittonia 57: 47-54.

This Article is brought to you for free and open access by the Herbarium at the University of Montana at ScholarWorks at University of Montana. It has been accepted for inclusion in University of Montana Herbarium Publications by an authorized administrator of ScholarWorks at University of Montana. For more information, please contact scholarworks@mso.umt.edu. 


\section{The resurrection of Erigeron parryi (Asteraceae)}

Author(s): Peter Lesica

Source: Brittonia, 57(1):47-54.

Published By: The New York Botanical Garden

DOI: http://dx.doi.org/10.1663/0007-196X(2005)057[0047:TROEPA]2.0.CO;2

URL: http://www.bioone.org/doi/full/10.1663/0007-196X\%282005\%29057\%5B0047\%3ATROEPA

$\% 5 \mathrm{D} 2.0 . \mathrm{CO} \% 3 \mathrm{~B} 2$

BioOne (www.bioone.org) is a nonprofit, online aggregation of core research in the biological, ecological, and environmental sciences. BioOne provides a sustainable online platform for over 170 journals and books published by nonprofit societies, associations, museums, institutions, and presses.

Your use of this PDF, the BioOne Web site, and all posted and associated content indicates your acceptance of BioOne's Terms of Use, available at www.bioone.org/page/terms_of_use.

Usage of BioOne content is strictly limited to personal, educational, and non-commercial use. Commercial inquiries or rights and permissions requests should be directed to the individual publisher as copyright holder. 


\title{
The resurrection of Erigeron parryi (Asteraceae)
}

\author{
Peter LesicA
}

Lesica, P. (Herbarium, Division of Biological Sciences, University of Montana, Missoula, MT 59812 and Montana Natural Heritage Program, 1515 E. Sixth Ave, Helena, MT 59620, U.S.A.; e-mail: peter.lesica@mso.umt.edu). The resurrection of Erigeron parryi. Brittonia 57: 47-54. 2005.-Erigeron parryi was described in 1890 from a single collection from southwest Montana. No additional collections were made during the following 90 years. Recent floristic treatments have synonomized E. parryi under E. ochroleucus. I used principal components and discriminant analyses of morphological characters to examine the relationship of E. parryi to its presumed closest relatives, E. ochroleucus, E. radicatus, and E. scribneri, in light of several populations discovered in the past 20 years. Erigeron parryi should be considered a distinct species. It can be readily distinguished from closely related species based on indument and caudex morphology. It is allopatric with E. ochroleucus and E. scribneri and ecologically separated from E. radicatus. Erigeron scribneri is intermediate between E. ochroleucus and E. radicatus and is probably best treated as a variety of one or the other of these species.

Key words: Asteraceae, Erigeron, Montana, Wyoming.

\section{Introduction}

Erigeron has its primary center of diversity in the mountainous regions of western North America where local endemism is common (Cronquist, 1947). The E. ochroleucus complex, consisting in part of $E$. ochroleucus Nutt., E. scribneri Canby ex Rydb. and E. radicatus Hook., has its center of distribution in Montana and Wyoming. Erigeron ochroleucus is found primarily at low to middle elevations, whereas $E$. radicatus generally occurs near or above treeline. Erigeron scribneri is found at all but the lowest elevations. These three sympatric taxa have taproots, linear leaves, and similar indument, but reportedly differ in size, vegetative vesture, and caudex branching. Most recently E. scribneri has been treated as a variety of E. ochroleucus (Cronquist, 1947, 1955; Dorn, 2001).

Another member of the Erigeron ochroleucus complex is E. parryi Canby \& Rose. It was first collected in 1888 by Frank Tweedy in extreme southwest Montana. The label reads, "dry hills, 7000 ft, Grass- hopper Creek, Beaverhead County." Erigeron parryi was described based on this one collection (Rose, 1890). This species was accepted by Rydberg (1954) and Booth and Wright (1959); however, Coulter and Nelson (1909) reduced both E. parryi and E. scribneri to synonymy under $E$. radicatus. Cronquist (1947) retained E. parryi in his monograph, stating:

Except for the dense and spreading pubescence of the stem and leaves, this plant suggests a small form of E. ochroleucus. The pubescence of the involucre and all the technical characters of the head are well within the limits of variability of E. ochroleucus. It seems probable that $E$. parryi is merely an unusual form of that species, but the difference in appearance of the pubescence is so marked that I hesitate to make an unqualified reduction without further evidence.

A few years later, however, he reduced E. parryi to synonomy under E. ochroleu- 
TABLE I

CHARACTERS AND THEIR STATES USED IN MULTIVARIATE ANALYSES AND MORPHOLOGICAL DESCRIPTIONS

Stem leaf number

Size

Stem height: to nearest $5 \mathrm{~mm}$

Middle stem leaf length: to nearest $1 \mathrm{~mm}$

Involucre height: to nearest $0.5 \mathrm{~mm}$

Involucre width: to nearest $0.5 \mathrm{~mm}$

Anatomy

Heads/stem: largest number

Persistent leaf bases: $0=$ none, $0.5=$ few, $1=$ clothes the caudex branch

Caudex branching order: $0=$ unbranched, $1=$ branched once, $2=$ twice branched etc.

Leaf and stem indument

Stem hair length: to nearest $0.1 \mathrm{~mm}$

Stem hair habit: 1 = appressed, $3=$ ascending, $5=$ erect

Stem hair density: to nearest 1 per $0.05 \mathrm{~mm}^{2}$ field

Leaf hair density: to nearest 1 per $0.05 \mathrm{~mm}^{2}$ field

Reproductive

Disk corolla length: to nearest $0.1 \mathrm{~mm}$

Ray color: 1 = white, $2=$ pink, $3=$ purple

$\%$ involucre hair with purple crosswalls: $0=$ none, $1=1 \%, 2=2-10 \%, 3 \geq 10 \%$

cus, stating that E. parryi was "a rare form with the herbage uniformly spreading hairy" (Cronquist, 1955). These statements suggest that Cronquist was uncomfortable maintaining a species based on a single collection made nearly seven decades earlier.

Several collections made in southwest Montana during the past 20 years fit the description of Erigeron parryi. The discovery of these populations warranted a re-evaluation of $E$. parryi. At the same time, it seemed appropriate to consider the taxonomic disposition of other sympatric members of this tight-knit complex. Erigeron lackschewitzii Nesom \& Weber is another similar species endemic to north-central Montana and thought to be most closely related to E. grandiflorus Greene (Nesom \& Weber, 1983), E. ochroleucus (Dorn, 1984; Nesom, 1989), or E. scribneri (Kerstetter, 1994). I did not consider E. lackschewitzii in this study.

\section{Methods}

\section{Plant Materials}

I scored 15 morphological characters considered important for separating the four members of the species complex (Cronquist, 1947; Kerstetter, 1994, pers. comm.; Table 1). I took measurements from one ( $E$. radicatus) or two (E. ochroleucus, E. scribneri) collections representative of those taxa in each county where they occur. Measurements were taken from specimens representing all known E. parryi populations. When possible, I took data from the largest and smallest specimens on each herbarium sheet in order to capture the full range of variation. A total of 245 specimens were measured: E. parryi $(N=22)$, E. ochroleucus $(N=109)$, E. radicatus $(N=28)$, and E. scribneri $(N=86)$. I examined specimens from University of Montana (MONTU), Montana State University (MONT), University of Wyoming (RM), University of Idaho (ID), and Brigham Young University (BRY).

A caudex is the woody, subterranean stem surmounting the taproot. I recorded the order of branching displayed by the caudex; e.g., if the branches are again branched, the branching is second order. I also scored the degree to which the woody caudex is clothed by old leaf bases which give it a ragged appearance. An intermediate score was given to plants in which only the uppermost few millimeters of caudex retained leaf bases. Stem hair orientation was scored $1-5 ; 1$ when most hair was tightly appressed to the stem; 5 when most 
hair was at right angles to the stem. I assigned intermediate classes when stem hairs displayed a mixture of orientations. For example, a mixture of appressed and ascending hair was scored as 2. I measured the density of hair in 2 or $30.05 \mathrm{~mm}^{2}$ frames under a $30 \times$ microscope. Stem hair density was measured at mid stem, while leaf hair density was measured on the adaxial surface of the upper half of the largest basal leaves.

I used stainability with analine blue dye as an indicator of pollen viability (Radford et al., 1974). I examined 100 randomly chosen pollen grains from each of five pressed plants from the Grasshopper Creek (Beaverhead Co.) and Victoria Mine (Madison Co.) populations. Grains were scored unviable if they were misshapen or failed to strongly take up the stain. This test assumes that presence of protoplasm indicates viable pollen, an assumption demonstrated in at least one instance (Kearns and Inouye, 1993; p. 111).

\section{DATA ANALYSIS}

I used principal components analysis (PCA) with all 15 characters to assess the degree and type of morphological divergence among taxa. Variables with loadings greater than 0.50 were considered important for determining a principal component (Manly, 1986). Backward stepwise discriminant analysis (DA) was employed to determine to what extent plants could be unambiguously assigned to a taxon and which characters best separated pairs of taxa. Analyses were performed using SYSTAT (SPSS, 2000). I assigned specimens to a taxon based on determinations made by authors of previous studies (Cronquist, 1947; Kerstetter, 1994) when possible or by using keys in floristic and monographic studies (Cronquist, 1947; Dorn, 2001). The two variables with the largest loadings were retained in the final discriminant function.

\section{Results}

The first two principal components explained $44 \%$ of the variation in the 15 measured variables and achieved the best separation of the four taxa (Fig. 1, Table 1).
The first principal component was clearly a size gradient. All five size characters (Table 1) and disk corolla length were important variables and were positively correlated (Table 2). The second principal component was a gradient of increasing density of leaf hair and clothing of the caudex with old leaf bases. The third principal component explained less than $10 \%$ of the variation and failed to separate any of the four taxa.

Results of the pairwise discriminant analyses are shown in Table 3. Erigeron parryi was accurately distinguished from other members of the complex ( $\geq 95 \%$ correct), and leaf hair density was the most distinct character. Discriminant analysis separated the other members of the complex on size characters and caudex branching. Erigeron ochroleucus and E. radicatus were accurately distinguished (98\% correct). However, E. scribneri was not well separated from either E. ochlorleucus or E. radicatus ( $\leq 88 \%$ correct).

Erigeron ochroleucus, E. scribneri, and E. radicatus are largely sympatric in Montana and Wyoming (Fig. 2). Erigeron ochroleucus is most common at lower elevations $(760-2890, \overline{\mathrm{x}}=1550 \mathrm{~m})$, while $E$. scribneri $(1070-2990, \overline{\mathrm{x}}=2280 \mathrm{~m})$ and $E$. radicatus $(1400-3380, \overline{\mathrm{x}}=2790 \mathrm{~m})$ occur most often at high elevations. Erigeron parryi occurs in Montana where E. ochroleucus and E. scribneri have not been collected. Erigeron parryi is sympatric with $E$. radicatus (Fig. 2), but it occurs at mid-elevations $(1360-2130, \overline{\mathrm{x}}=1755 \mathrm{~m})$. All four taxa are common only east of the Continental Divide.

A mean of $88 \%(\mathrm{SD}=7 \%)$ of Erigeron parryi pollen grains were well-formed and stained deeply with analine blue. Mean stainability was $92 \%$ and $83 \%$ for the Victoria Mine and Grasshopper Creek populations, respectively.

\section{Discussion}

Erigeron parryi appears to be distinct from other members of the E. ochroleucus complex. As noted by Cronquist (1947), it differs by having leaves and stems covered with dense, erect hair. This indument is quite different from the appressed, sparse 


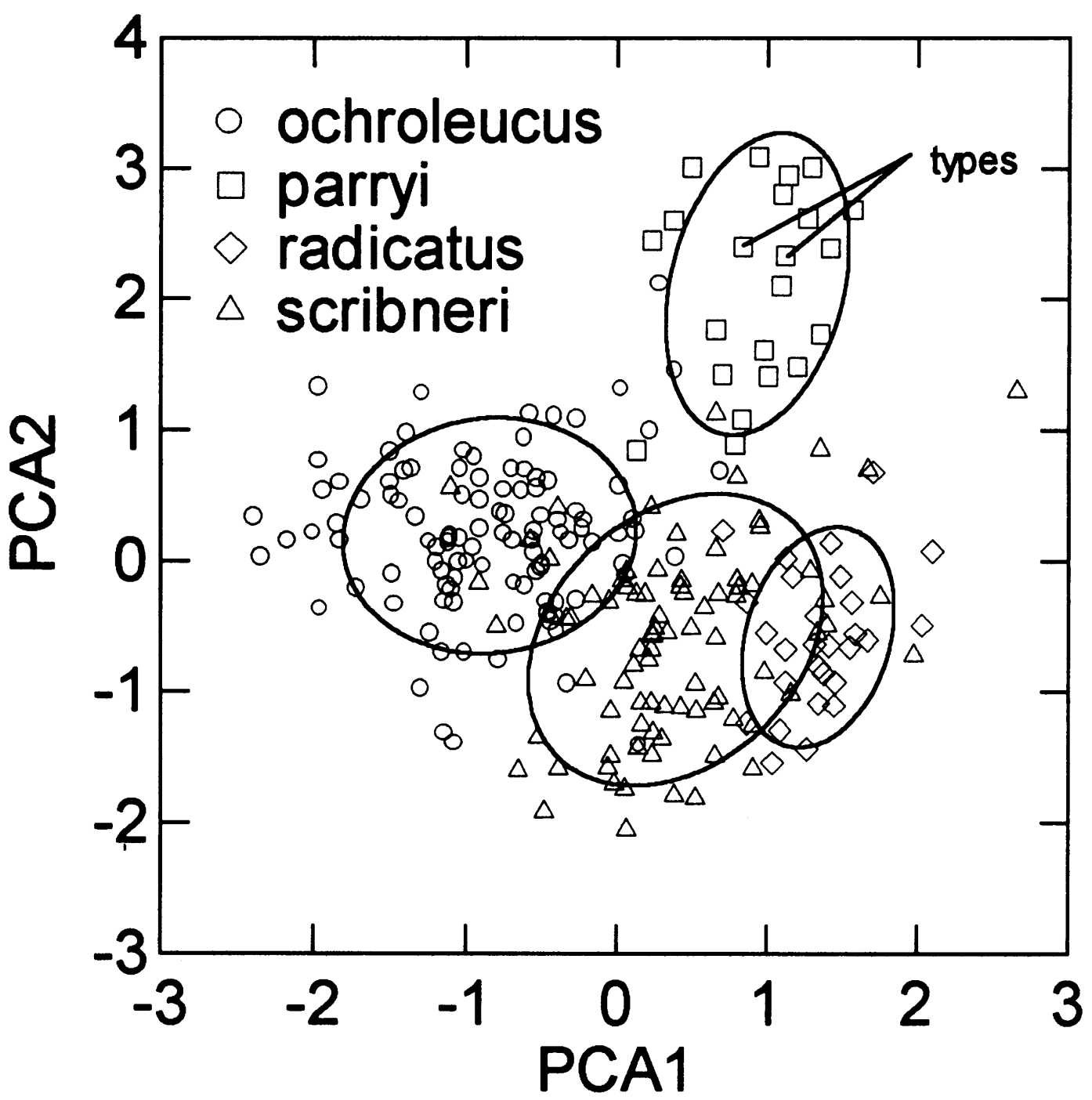

Fig. 1. Principal components analysis of four Erigeron taxa based on 15 morphological characters (see Table 2). Ellipses enclose scores within one standard deviation of the centroid for each taxon. Plants representing the types of E. parryi are indicated.

hair of the other three taxa. In addition, the caudex of $E$. parryi is regularly clothed in old leaf bases, whereas this trait is uncommon in the other three taxa. Erigeron parryi apparently occurs outside the range of $E$. ochroleucus and E. scribneri (Fig. 2). Both $E$. parryi and E. scribneri occur in Broadwater County, but the former was found at low elevations in the western portion of the county, while the latter was collected at high elevations in the northeastern part of the county. Erigeron parryi and E. radicatus are sympatric, but are well separated on an elevational gradient where both occur in Montana.

Erigeron ochroleucus and E. radicatus also seem distinct. The former is larger, usually with four or more stem leaves, whereas the latter is rarely more than $3 \mathrm{~cm}$ high with fewer than four stem leaves. A branched caudex is rare in E. ochroleucus but common in E. radicatus. Erigeron rad- 
TABLE II

RESULTS OF PRINCIPAL COMPONENTS ANALYSIS. IMPORTANT FACTOR LOADINGS $(>0.5)$ ARE IN BOLD

\begin{tabular}{lrrr}
\hline \hline & PCA1 & PCA2 & \multicolumn{1}{c}{ PCA3 } \\
\hline Variation explained & $30.4 \%$ & $13.0 \%$ & \multicolumn{1}{c}{$9.2 \%$} \\
Stem height & $-\mathbf{0 . 8 6 1}$ & 0.201 & -0.186 \\
Stem leaf number & $\mathbf{- 0 . 8 1 5}$ & 0.178 & -0.094 \\
Stem leaf length & $-\mathbf{0 . 7 7 6}$ & 0.144 & -0.047 \\
Involucre height & $\mathbf{- 0 . 6 2 8}$ & -0.056 & 0.110 \\
Involucre width & $-\mathbf{0 . 7 3 6}$ & -0.106 & 0.332 \\
Heads/stem & -0.327 & 0.499 & -0.122 \\
Persistent leaf bases & 0.355 & $\mathbf{0 . 6 1 9}$ & 0.208 \\
Caudex branching & 0.456 & 0.071 & -0.110 \\
Stem hair length & 0.164 & 0.094 & -0.377 \\
Stem hair habit & $\mathbf{0 . 7 0 0}$ & 0.398 & 0.053 \\
Stem hair density & 0.292 & 0.129 & $\mathbf{0 . 5 6 7}$ \\
Leaf hair density & 0.259 & $\mathbf{0 . 7 5 1}$ & 0.302 \\
Disk corolla length & $-\mathbf{0 . 5 9 1}$ & 0.087 & $\mathbf{0 . 5 2 7}$ \\
Ray color & 0.031 & -0.391 & $\mathbf{0 . 5 3 5}$ \\
Purple crosswalls & 0.409 & $-\mathbf{0 . 5 8 1}$ & 0.137 \\
\hline
\end{tabular}

icatus often has involucre hairs with purple crosswalls, whereas this is rare in E. ochroleucus. Erigeron radicatus generally occurs at higher elevations than E. ochroleucus. These two taxa have usually been considered distinct species (Rydberg, 1954; Cronquist, 1947, 1955; Dorn, 2001).

Erigeron scribneri appears intermediate between E. ochroleucus and E. radicatus, overlapping these two species in most characters (Fig. 1). Results of DA indicate that E. scribneri cannot be reliably differentiated from either of the other species using the characters measured in this study (Table 3 ). Erigeron scribneri was reduced to synonomy with E. radicatus by Coulter and Nelson (1909). Cronquist (1947) relegated $E$. scribneri to a variety of E. ochroleucus, noting that the only significant characters separating two taxa were related to size, and

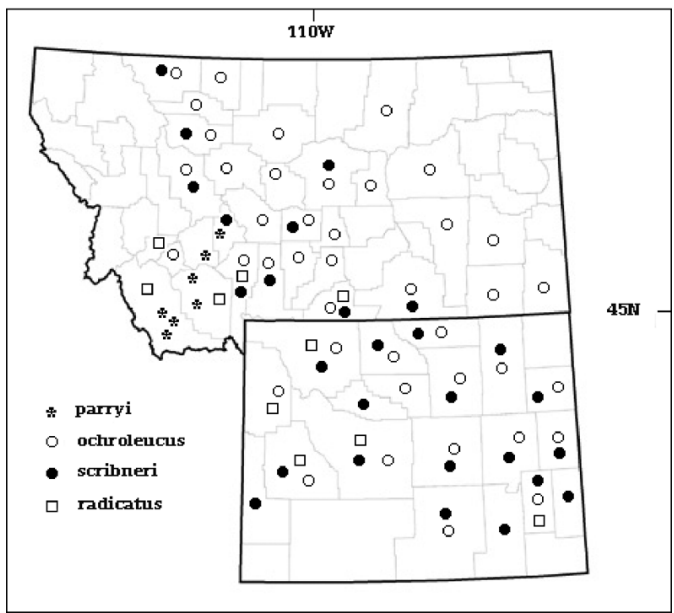

Fig. 2. Distribution of four Erigeron taxa in Montana and Wyoming.

there were many intermediates. Results of my study confirm Cronquist's observations. Cronquist (1947) believed that E. ochroleucus var. scribneri has more finely hairy stems and less caudex branching than $E$. radicatus, and Dorn (2001) separated the taxa on disk corolla size and number of pappus bristles. I did not measure pappus bristle number, but results from my study indicate there is a good deal of overlap between the two taxa in the other characters. Kerstetter (1994) speculated that E. radicatus may be a hybrid of which $E$. scribneri is one parent. It seems best to retain Cronquist's taxonomic disposition of E. scribneri as a variety of E. ochroleucus because it is not distinct, and there is currently not enough information to demonstrate that it is more closely related to E. radicatus.

Pollen stainability is consistent with

TABLE III

IMPORTANT CHARACTERS SEPARATING PAIRS OF TAXA IN Erigeron, AS DETERMINED BY STEPWISE DISCRIMINANT ANALYSIS. A JACKNIFE PROCEDURE WAS USED TO ESTIMATE THE PROPORTION OF PLANTS CORRECTLY CLASSIFIED FOR EACH PAIR.

\begin{tabular}{llr}
\hline \hline \multicolumn{1}{c}{ Species pairs } & \multicolumn{1}{c}{ Important characters } & Correctly classified \\
\hline ochroleucus, scribneri & stem height, leaf number & $88 \%$ \\
radicatus, scribneri & involucre height, caudex branching & $78 \%$ \\
ochroleucus, radicatus & leaf number, caudex branching & $98 \%$ \\
parryi, ochroleucus & leaf hair density, hair habit & $95 \%$ \\
parryi, radicatus & leaf hair density, corolla length & $100 \%$ \\
parryi, scribneri & leaf hair density, number of heads & $97 \%$ \\
\hline
\end{tabular}




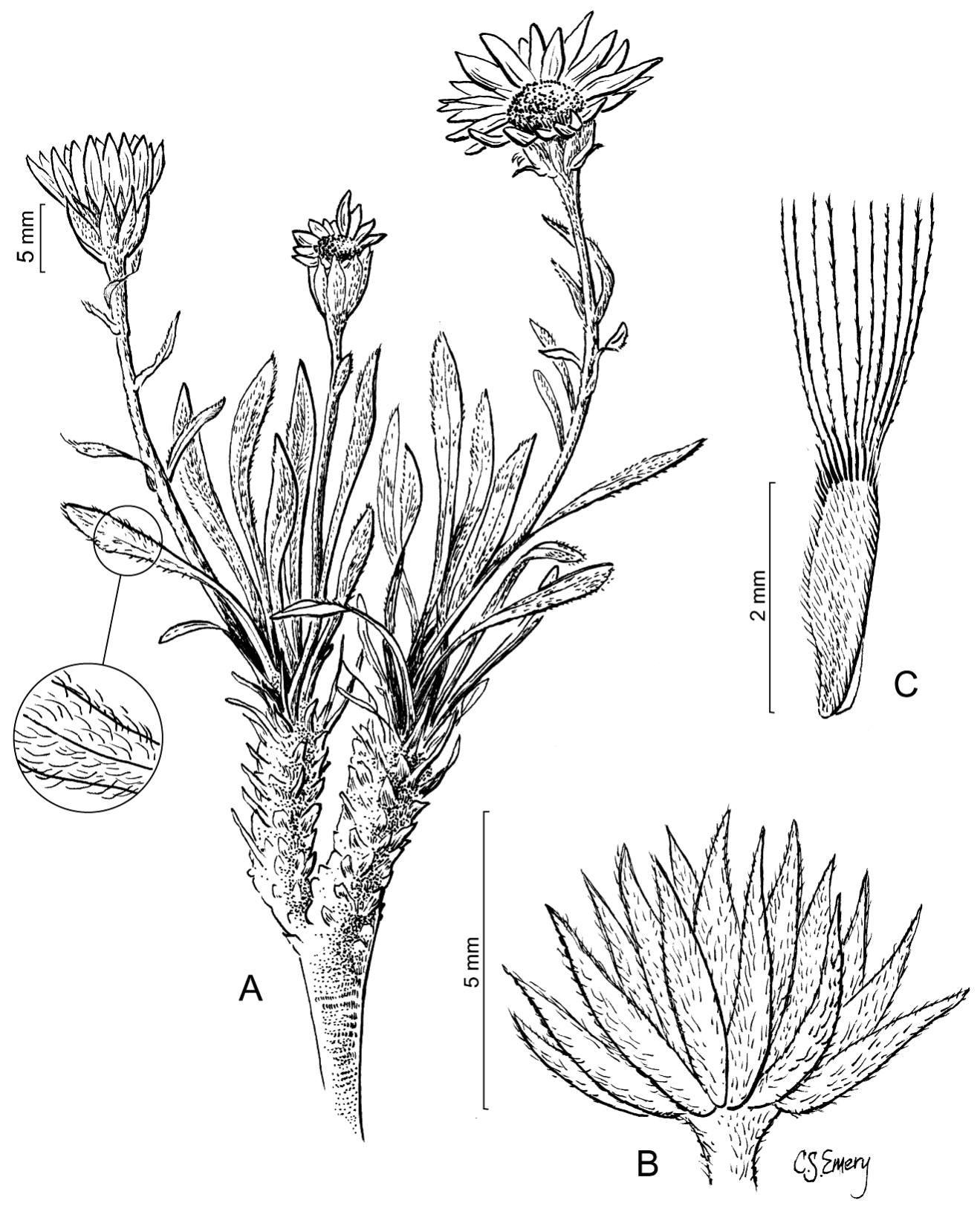

Fig. 3. Illustration of Erigeron parryi. A. Whole plant B. Involucre C. Achene (From Lesica 8649 MONTU).

Erigeron parryi being a sexually reproducing species. Erigeron lackschewitzii, another local member of the E. ochroleucus complex in Montana (Nesom \& Weber, 1983), has unviable pollen and apparently produces seed agamospermously (Kerstetter, 1994); however, this does not appear to be the case with $E$. parryi.
I present a description of Erigeron parryi because previous ones were based on a single collection.

ERIGeron Parryi Canby \& Rose, Bot. Gaz. 15:65, 1890. TYPE: UNITED STATES. Montana: Beaverhead Co., Grasshopper Creek, dry hills, 7000 ft, Jul 1888, F. 
Tweedy 15; (LECTOTYPE here designated, GH; ISOTYPES: MONT, NY, US, YU).

Perennial herb with an unbranched taproot surmounted by a simple or branched, woody caudex clothed in old leaf bases; stems simple or sparingly branched, 2-15 $\mathrm{cm}$ tall, densely strigose with ascending and spreading, white hairs ca. $0.5 \mathrm{~mm}$ long; basal leaves linear, widened and whitish at the base, 1-6 cm long and 0.5-2 $\mathrm{mm}$ wide with indument similar to the stem; cauline leaves 3-8, linear $0.5-2 \mathrm{~cm}$ long, reduced upward; heads 1-3 per stem; involucre hemispheric, 4-9 $\mathrm{mm}$ tall and 8-12 $\mathrm{mm}$ wide pressed; phyllaries in 1-2 equal series, herbaceous, green, often purplish toward the tip, narrowly lanceolate, white-tomentose with multicellular hairs ca. $1 \mathrm{~mm}$ long and short unicellular hairs, rarely with purple crosswalls at the base, sparsely covered with granular glands; ray flowers fertile 2040 , white but sometimes drying pink, lobed style exposed at the mouth, the tube sparsely hairy and ca. $2 \mathrm{~mm}$ long; ligules $5-8 \mathrm{~mm}$ long, 1-2.5 mm wide, erect to spreading; disc corollas tubular, yellow with darkened lobes, glabrous to sparsely hairy, 2.5-4.0 mm long; anthers $0.9-1.5 \mathrm{~mm}$ long; stigma lobes $0.6-0.9 \mathrm{~mm}$; achenes compressed, 2nerved, 1.5-2 mm long, sparsely to moderately covered with unicellular hairs and sessile glands; pappus of 12-18 brittle capillary bristles ca. as long as the disk corolla tube and ca. 20 outer bristles or squamellae ca. $0.3 \mathrm{~mm}$ long; (Fig. 3).

Locally common in sparsely vegetated, stony, limestone-derived soil of slopes and ridge crests in the sagebrush zone (1350$2135 \mathrm{~m}$ ) of Beaverhead, Broadwater, Jefferson, and Madison counties, Montana. Flowering in June and July.

Additional specimens examined. UNITED
STATES. Montana. Beaverhead Co., above Grasshopper Creek, 5500 ft, 12 Jun 1984, P. Lesica 2995 (MONTU); Red Butte NW of Lima, $6200 \mathrm{ft}, 6 \mathrm{Jul}$ 1986, P. Lesica 3928 (MONTU, NY); above Muddy Creek, 7000 ft, 27 Jun 1987, K. Lackschewitz, 11307 (MONTU, NY); same location, 9 Jul 1993, P. Lesica 6063 (MONTU); 2 mi S of Grasshopper Creek, 6200 ft, 23 Jun 2003, P. Lesica 8657 (CA, MONT, MONTU, NY, RM). Broadwater Co., $1 \mathrm{mi} \mathrm{S}$ of Spokane Hills, 14 May 1998, P. Vanderhorst s.n. (MONT). Jefferson Co., NE of Cardwell, 5200 ft, 31 May 1991, Lesica 5347 (MONTU); same location, 2 Jun 1993, J. Vanderhorst 4899 (MONT) Vanderhorst 4899 (MONT); same location, 17 Jun 2003, P. Lesica 8630 (CA, MONT, MONTU, RM). Madison Co., Trudeau Warm Spring, 5500 ft, $10 \mathrm{Jul}$ 1983, P. Lesica 2712 (MONTU), ca. $1 \mathrm{mi} \mathrm{S}$ of Victoria Mine, $5250 \mathrm{ft}, 2 \mathrm{Jul}$ 1994, P. Lesica 6345 (MONT, MONTU); same location, 21 Jun 1995, T. Kerstetter 3801 (CA, MONT, MONTU, NY, RM); same location, 18 Jun 2003, P. Lesica 8640 (CA, MONT, MONTU, NY, RM), S of Ruby Reservoir, $5600 \mathrm{ft}, 28$ May 1983, K. Lackschewitz 10426 (MONTU); same location, 19 Jun 2003, P. Lesica 8645 (MONTU, RM).

The exact location for the type collection is not known. Erigeron parryi is common on the slopes of Grasshopper Creek below Bannack at elevations at or below $1830 \mathrm{~m}$. However, limestone is not common along Grasshopper Creek at elevations of $2135 \mathrm{~m}$ $(7000 \mathrm{ft})$ as reported by Tweedy. I searched several areas around Bannack and farther upstream at elevations closer to $2135 \mathrm{~m}$ but was unable to locate the plant. Perhaps Tweedy reported the wrong elevation, but this seems unlikely because he was a civil engineer by trade.

Erigeron parryi is named for Charles C. Parry, a medical doctor turned botanist who served as the botanist of the United StatesMexico Boundary Survey from 1849 to 1852. He was the first botanist for the United States Department of Agriculture and was at the Smithsoniam Institution from 1869 to 1971 . Many new taxa were discovered by Parry during almost 40 years of collecting.

\section{Erigeron parryi may be distinguished from its presumed closest relatives by the following key.}

1. Stems and leaves canescent with dense, ascending or erect hairs; caudex thickened by presence of old leaf bases well below the current leaves

1. Stems and leaves green, leaf hair sparse and appressed; caudex not thickened, old leaf bases usually present only just below the leaves.

2. Caudex usually branched; basal leaves mostly glabrous; leaves of well-developed plants usually 1-2 per stem 
2. Caudex usually unbranched; basal leaves with sparse appressed hair; stem leaves of well-developed plants three or more.

3. Stems of well-developed plants to $6 \mathrm{~cm}$ high; stem leaves 5 or fewer per stem; plants often subalpine or higher E. ochroleucus var. scribneri

3. Stems of well-developed plants greater than $6 \mathrm{~cm}$ high; stem leaves of well developed plants less than 5; plants primarily of valleys and foothills E. ochroleucus var. ochroleucus

\section{Acknowledgments}

Funding was provided by the Montana Office of the Bureau of Land Management. Tulli Kerstetter, Matt Lavin, and Arnold Tiehm gave advice and encouragement. Guy Nesom and Ron Hartman provided helpful comments on the manuscript. James Reveal and Kanchi Gandhi advised me on lectotypification. Stuart Markow (RM) and Cathy Seibert (MONT) helped me select specimens. Alan Cox helped prepare the map. Lila Fishman and Dena and Kerry Foresman helped with the pollen stainability study. Claire Emery prepared the illustration of Erigeron parryi. I am grateful to the curators of BRY, GH, ID, MONT, NY, RM, US and YU for allowing use of their specimens. This paper is dedicated to the memory of Arthur Cronquist who helped me with many past projects.

\section{Literature Cited}

Booth, W. E. \& J. C. Wright. 1959. Flora of Montana, Part II. Montana State University, Bozeman.

Coulter, J. M. \& A. Nelson. 1909. New manual of botany of the Central Rocky Mountains. American Book Company, New York.

Cronquist, A. 1947. Revision of the North American species of Erigeron, north of Mexico. Brittonia 6: 121-302.

. 1955. Compositae. Pages 1-343. In: C. L. Hitchcock, A. Cronquist, M. Owenby and J. W. Thompson, editors. Vascular plants of the Pacific Northwest. Part 5. University of Washington Press, Seattle.

Dorn, R. D., 1984. Vascular Plants of Montana. Mountain West Publishing. Cheyenne, WY. . 2001. Vascular plants of Wyoming. Mountain West Publishing, Cheyenne, Wyoming.

Kearn, C. A. \& D. W. Inouye. 1993. Techniques for pollination biologists. University Press of Colorado, Niwot.

Kerstetter, T. A. 1994. Taxonomic investigation of Erigeron lackschewitzii. M.S. thesis. Montana State University, Bozeman.

Manly, B. F. J. 1986. Multivariate statistics. Chapman and Hall, London.

Nesom, G. L. 1989. Infrageneric taxonomy of New World Erigeron (Compositae: Astereae). Phytologia 67: 67-93.

\& W. A. Weber. 1983. A new woolly-headed, monocephalous Erigeron (Asteraceae) from Montana. Madrono 30: 245-249.

Radford, A. E., W. C. Dickison, J. R. Massey \& C. R. Bell. 1974. Vascular plant systematics. Harper and Row, New York.

Rose, J. N. 1890. Notes on some western plants. Bot. Gaz. 15: 63-67.

Rydberg, P. A. 1954. Flora of the Rocky Mountains and adjacent plains. 2nd ed. Hafner Publishing, New York.

SPSS Inc. 2000. SYSTAT. SPSS Inc., Chicago. 